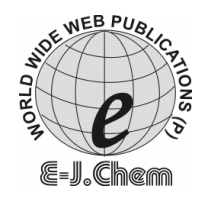

http://www.e-journals.net
ISSN: 0973-4945; CODEN ECJHAO

E-Journal of Chemistry 2010, 7(2), 349-352

\title{
Assessment of Heavy Metals in Water Samples of Certain Locations Situated Around Tumkur, Karnataka, India
}

\author{
C.VIJAYA BHASKAR ${ }^{\S}$, KIRAN KUMAR and G. NAGENDRAPPA* \\ *Department of Studies in Chemistry, \\ Manasagangothri, University of Mysore, Mysore-570006, Karnataka, India. \\ ${ }^{\S}$ Sri Siddhartha First Grade college, Tumkur-572105, India. \\ Forensic Laboratary, Madiwala, Bangalore, Karnataka, India. \\ gnagendrappa@yahoo.co.in
}

Received 30 January 2009; Accepted 20 March 2009

\begin{abstract}
Surface water and groundwater samples of certain locations namely Kallambella, Bugudanahalli, Maidala, Honnudike, Kunigal, Kadaba and Hebbur, situated around Tumkur were assessed in the month of September 2008 for pH, EC and heavy metals $\mathrm{Cd}, \mathrm{Cu}, \mathrm{Fe}, \mathrm{Hg}, \mathrm{Mn}, \mathrm{Zn}$ and $\mathrm{Ni}$. The $\mathrm{pH}$ vales of surface waters were in alkaline range of 7.8-8.2 and are well within safe limits for crop production. The $\mathrm{pH}$ of groundwater was in the range of 7.6-8.4. The conductivity was in the range of $0.20-0.68 \mathrm{mS} / \mathrm{cm}$ and $0.34-2.44 \mathrm{mS} / \mathrm{cm}$ for surface and groundwaters respectively. High EC value of Kallambella groundwater accounts for its salinity. All surface waters except Honnudike and Hebbur samples contain low concentrations of these metals and are ideal for irrigation. Though the samples from Honnudike, Kadaba and Hebbur have high iron concentration, only Honnudike and Hebbur samples have exceeded the limit of $5 \mathrm{mg} / \mathrm{L}$ required for irrigation. In groundwaters the concentrations of all these heavy metals except copper are also well in permissible limits and suitable for drinking. $\mathrm{Cu}, \mathrm{Fe}, \mathrm{Ni}$ and $\mathrm{Zn}$ were detected in all the samples and found in the range of 0.094-0.131, 0.958-12.537, 0.020-0.036 and $0.082-1.139 \mathrm{mg} / \mathrm{L}$ respectively in surface waters and these are in the range of $0.132-0.142,0.125-1.014,0.028-0.036$ and $0.003-0.037 \mathrm{mg} / \mathrm{L}$ in ground- waters. The elements cadmium, mercury and manganese are absent in all the samples.
\end{abstract}

Keywords: Surface waters, Groundwaters, Heavy metals, Irrigation. 


\section{Introduction}

Heavy metals are environmentally stable and non-biodegradable, toxic to the living beings and tend to accumulate in plants and animals causing chronic adverse effects on human health. Heavy metals are introduced to the environment through a variety of sources such as combustion, extraction, agricultural runoff, transportation etc ${ }^{1}$. Heavy metals are priority toxic pollutants that severely limit the beneficial use of water for domestic and industrial application ${ }^{2}$. Frequent use of heavy metal contaminated water in the agricultural fields leads to soil pollution and gradually enriched the soil with heavy metals. Different studies have revealed that the presence of toxic heavy metals like $\mathrm{Fe}, \mathrm{Pb}, \mathrm{Hg}$ reduce soil fertility and agricultural output ${ }^{3}$. The lakes have complex and fragile ecosystem, as they do not have self cleaning ability and therefore readily accumulate pollutants ${ }^{4}$.

Though some of the metals like $\mathrm{Cu}, \mathrm{Fe}, \mathrm{Mn}, \mathrm{Ni}$ and $\mathrm{Zn}$ are essential as micro nutrients for plants and microorganisms, many other metals like $\mathrm{Cd}, \mathrm{Cr}$ and $\mathrm{Pb}$ are proved detrimental beyond a certain limit ${ }^{5}$. With sufficient surface water infiltration, soil contaminants such as heavy metals can leach to underlying groundwater. The effects of heavy metals on groundwater are different for different types of soils ${ }^{6}$. Occurrence of heavy metals in groundwater were directly related to soil characteristics that determine the rate of water movement ${ }^{7}$. According to $\mathrm{WHO}^{8}$, copper is rarely found in natural water, consequently its existence in high concentration in waters within the area of study is an index of pollution from leachates and effluents of the polluted environments where the water sources are located.

\section{Experimental}

A total of 14 water samples (7 surface water samples and 7 groundwater samples) were collected from lakes and nearby hand pumps of the selected areas around Tumkur namely Kallambella, Bugudanahalli, Mydala, Honnudike, Kunigal, Kadaba and Hebbur and preserved with $2 \mathrm{~mL}$ nitric acid to prevent the precipitation of metals. The samples were then concentrated and subjected to nitric acid digestion. Heavy metal analyses were carried out using inductively coupling plasma method. The $\mathrm{pH}$ of water samples was determined by a pH-meter and conductivity was measured by a conductivity meter (Systronics).

\section{Results and Discussion}

\section{Surface waters}

The surface waters exhibited an alkaline $\mathrm{pH}$ range of 7.6-8.2 but the values are well within the safe limit of crop production ${ }^{9}$. Higher levels of $\mathrm{pH}$ and alkalinity tend to reduce toxicity of metals in water ${ }^{10}$. The most influential water quality parameter on crop productivity is the water salinity hazard as measured by electrical conductivity. The primary effect of water having high EC on crop productivity is the inability of the plant to compete with ions in the soil solution for water. The higher the EC, the less water is available to plants, even though the soil may appear wet. Water with electrical conductivity less than $0.7 \mathrm{mScm}^{-1}$ is considered to be safe but in the range of $0.7-3 \mathrm{mScm}^{-1}$ may cause little to moderate salinity problems ${ }^{11}$. However in the present study, the conductivity values of waters are in the range of $0.20-0.68 \mathrm{mS} / \mathrm{cm}$ and are suitable for crop production. The analysis of surface waters for $\mathrm{Cd}, \mathrm{Fe}, \mathrm{Cu}, \mathrm{Hg}, \mathrm{Mn}, \mathrm{Zn}$ and $\mathrm{Ni}$ revealed that all the samples, except Honnudike, Kadaba and Hebbur samples have very low concentrations of these elements and are suitable for irrigation. However, the samples from Honnudike and Hebbur have more $\mathrm{Fe}$ concentration and exceeded the limit of $5 \mathrm{mg} / \mathrm{l}$ required for irrigation waters ${ }^{12}$. Though Kadaba waters have excess iron concentration, the value is well in limit of $5 \mathrm{mg} / \mathrm{L}$ (Table1). 
Table 1. pH, EC (mS/cm) and Concentrations of heavy metals $(\mathrm{mg} / \mathrm{L})$

\begin{tabular}{cccccccccc}
\hline Locations & $\mathrm{pH}$ & $\mathrm{EC}$ & $\mathrm{Cd}$ & $\mathrm{Cu}$ & $\mathrm{Hg}$ & $\mathrm{Fe}$ & $\mathrm{Mn}$ & $\mathrm{Ni}$ & $\mathrm{Zn}$ \\
\hline Kallambella & 8.2 & 0.34 & $\mathrm{Nil}$ & 0.095 & $\mathrm{Nil}$ & 3.994 & -0.066 & 0.032 & 1.139 \\
Bugudanahalli & 8.0 & 0.20 & $\mathrm{Nil}$ & 0.120 & $\mathrm{Nil}$ & 0.958 & -0.148 & 0.021 & 0.082 \\
Mydala & 7.6 & 0.44 & $\mathrm{Nil}$ & 0.113 & $\mathrm{Nil}$ & 0.992 & -0.144 & 0.021 & 0.140 \\
Honnudike & 8.0 & 0.68 & $\mathrm{Nil}$ & 0.094 & $\mathrm{Nil}$ & 9.783 & -0.092 & 0.026 & 0.263 \\
Kunigal & 7.8 & 0.22 & $\mathrm{Nil}$ & 0.131 & $\mathrm{Nil}$ & 1.057 & -0.139 & 0.020 & 0.222 \\
Kadaba & 7.9 & 0.28 & $\mathrm{Nil}$ & 0.118 & $\mathrm{Nil}$ & 2.038 & -0.146 & 0.024 & 0.391 \\
Hebbur & 7.8 & 0.26 & $\mathrm{Nil}$ & 0.118 & $\mathrm{Nil}$ & 12.537 & -0.123 & 0.036 & 0.744 \\
FAO & - & - & - & 0.2 & - & 5.0 & 0.2 & 0.2 & - \\
\hline
\end{tabular}

\section{Groundwaters}

The groundwaters also have the alkaline $\mathrm{pH}$ range of 7.6-8.4 and the values are well within the safe limit for drinking ${ }^{13}$. These waters have the conductivity range of $0.34-1.86 \mathrm{mScm}^{-1}$. The analysis of heavy metals in these waters have revealed that (Table 2), except $\mathrm{Cu}$, the concentrations of all other elements namely $\mathrm{Fe}, \mathrm{Zn}$ and $\mathrm{Ni}$ are within the safe limit for drinking set by BIS ${ }^{14}$. The low concentration of zinc in drinking water could be due to the fact that $\mathrm{pH}$ of water samples were slightly alkaline and its solubility is a function of decreasing $\mathrm{PH}^{15}$. Low intake of zinc results in growth retardation, immaturity and anemia $^{16}$. The relative dominance of heavy metals in all the samples are in the order of $\mathrm{Fe}>\mathrm{Cu}>\mathrm{Zn}>\mathrm{Ni}$ except for the samples from Kunigal, Kadaba and Hebbur where the order is $\mathrm{Fe}>\mathrm{Cu}>\mathrm{Ni}>\mathrm{Zn}$. The concentrations of Fe varied from 0.125 to $1.014 \mathrm{mg} / \mathrm{L}, \mathrm{Cu}$ from 0.132 to $0.142 \mathrm{mg} / \mathrm{L}$, Ni from 0.028 to $0.036 \mathrm{mg} / \mathrm{L}$ and $\mathrm{Zn}$ from 0.003 to $0.051 \mathrm{mg} / \mathrm{L}$. The Fe concentration of Bugudanahalli water is slightly exceeding the drinking water limit of $0.3 \mathrm{mg} / \mathrm{L}$ set by BIS, 1991. Long term consumption of drinking water with high concentration of iron may lead to liver diseases ${ }^{17}$. All the samples have higher $\mathrm{Cu}$ concentrations and exceeding the limit of BIS value, $0.05 \mathrm{mg} / \mathrm{L}$ for drinking. Though copper is not a cumulative systemic poison, large dose $(>1.0 \mathrm{mg})$ is harmful and might cause central nervous system disorder, failure of pigmentation of hair and effects on $\mathrm{Fe}$ metabolism ${ }^{18}$.

Table 2. $\mathrm{pH}, \mathrm{EC}(\mathrm{mS} / \mathrm{cm})$ and concentrations of heavy metals $(\mathrm{mg} / \mathrm{L})$

\begin{tabular}{cccccccccc}
\hline Locations & $\mathrm{pH}$ & $\mathrm{EC}$ & $\mathrm{Cd}$ & $\mathrm{Cu}$ & $\mathrm{Hg}$ & $\mathrm{Fe}$ & $\mathrm{Mn}$ & $\mathrm{Ni}$ & $\mathrm{Zn}$ \\
\hline Kallambella & 8.4 & 2.44 & $\mathrm{Nil}$ & 0.132 & $\mathrm{Nil}$ & 0.274 & -0.159 & 0.030 & 0.037 \\
Bugudanahalli & 7.8 & 0.66 & $\mathrm{Nil}$ & 0.136 & $\mathrm{Nil}$ & 1.014 & -0.156 & 0.028 & 0.029 \\
Mydala & 7.6 & 0.34 & $\mathrm{Nil}$ & 0.139 & $\mathrm{Nil}$ & 0.242 & -0.159 & 0.036 & 0.051 \\
Honnudike & 8.3 & 1.68 & $\mathrm{Nil}$ & 0.142 & $\mathrm{Nil}$ & 0.683 & -0.192 & 0.028 & 0.048 \\
Kunigal & 7.8 & 0.62 & $\mathrm{Nil}$ & 0.142 & $\mathrm{Nil}$ & 0.125 & -0.156 & 0.031 & 0.012 \\
Kadaba & 7.9 & 0.58 & $\mathrm{Nil}$ & 0.137 & $\mathrm{Nil}$ & 0.128 & -0.159 & 0.031 & 0.015 \\
Hebbur & 7.6 & 0.92 & $\mathrm{Nil}$ & 0.142 & $\mathrm{Nil}$ & 0.130 & -0.156 & 0.034 & 0.003 \\
WHO, 1971 & - & - & 0.01 & 1.0 & 0.001 & 1.0 & 0.5 & - & 5.0 \\
BIS,1991 & - & - & 0.01 & 0.05 & 0.001 & 0.3 & 0.1 & - & 5.0 \\
\hline
\end{tabular}

\section{Conclusions}

All the surface water samples except samples of Honnudike and Hebbur were found to be having normal concentrations of heavy metals and fit for irrigation purpose. However, Hebbur and Honnudike samples have iron concentrations exceeding the limit set for irrigation purpose. 
All the groundwater samples under study have normal concentrations of iron and nickel, lower concentrations of zinc, and higher concentrations of copper. Cadmium, mercury and manganese are found to be absent in all the samples.

\section{Acknowledgment}

The first author is immensely grateful to the management of Sri Siddhartha First Grade College, Tumkur for their motivation and support in pursuing research activities. He is also thankful to the coordinator Dr Y.M.Reddy, Principal Prof. H.N.Vijayendra, Dr M.B.Nadoni, Sri K.S.Kumar, M.S.Jayaprakash and S.Krishnamurthy for their suggestions and cooperation. A special thanks to Dr.B.Mohan, Director, FSL, Bangalore for providing ICP facility.

\section{References}

1. Lars Jarup, British Medical Bulletin, 2003, 68, 167-182.

2. $\quad$ Petrus R and Warchol J K, Water Res., 2005, 39, 819-830.

3. Lokhande R S and Kelkar N, Indian J Environ Protect.,1999, 19, 664-668.

4. Lokeshwari H and Chandrappa G T, Curr Sci., 2006, 91(5), 584.

5. Bruins M R, Kapil S and Oehme F W, Ecotox Environ Safe, 2000, 45, 198-207.

6. Zenglu Xia, Soil environmental capacity of China, Earthquake Publishing, 1992.

7. Burkat M R, Kolpin D W, Jaquis R J and Cole K J, J Environ Qual., 1999, 26,1908-1915.

8. WHO, Guidelines for drinking water quality, Geneva, 1984.

9. FAO, Manual of methods in aquatic environment research, Food and Agricultural Organization of the United Nations, part 1, Methods of detection, measurement and monitoring of water pollution, 1975.

10. Train R E, Quality Criteria for Water. U.A.EPA Washigton D.C, 1979, 256.

11. Vijaya Bhaskar C, Mahadevaiah and Nagendrappa G, Indian J Environ Ecoplan, 2008, 15(1-2), 105-110.

12. Kar D, Sur P, Mandal S K, Saha T and Kole R K, Int J Environ Sci Tech., 2001, 5(1), 119-124.

13. WHO, World Health Organization technical report series No.532, Geneva, 1973.

14. BIS, Indian Standards Drinking Water specifications. Bureau of Indian Standard, 1991, 10500.

15 Aamir Ilyas and Tahir Sarwar, Pakistan J Biol Sci., 2003, 6(1), 86-91.

16. Halsted J A, Am.J.Med., 1972, 53, 277.

17. Mehta M B, J Ind Poll Contr., 2003, 19(2),153-157.

18. Mohammed M AL-Subu, Marwan Haddad, Numan Mizyed and Inaya Mizyed, Water Air Soil pollut., 2003, 146,141-152 




International Journal of

Medicinal Chemistry



Carbohydrate Chemistry

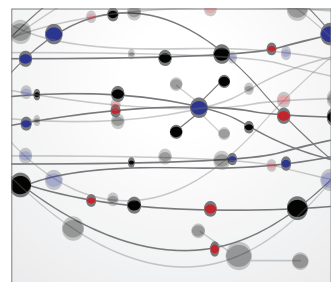

The Scientific World Journal
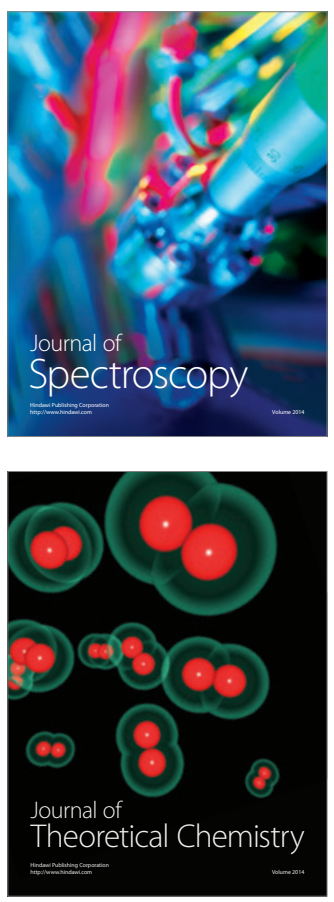
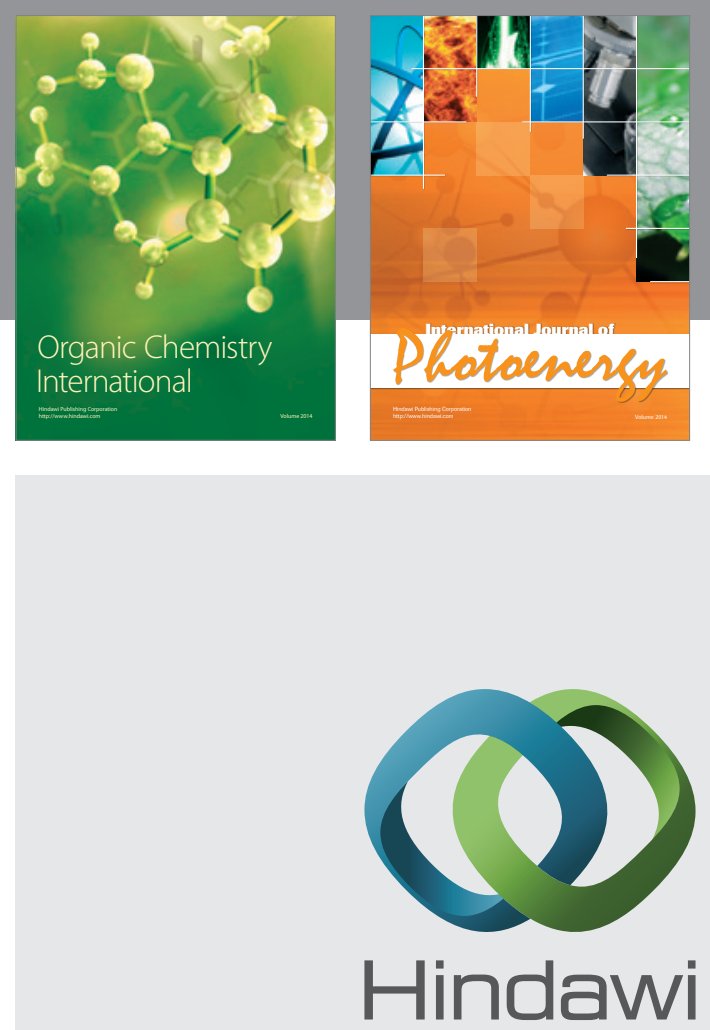

Submit your manuscripts at

http://www.hindawi.com
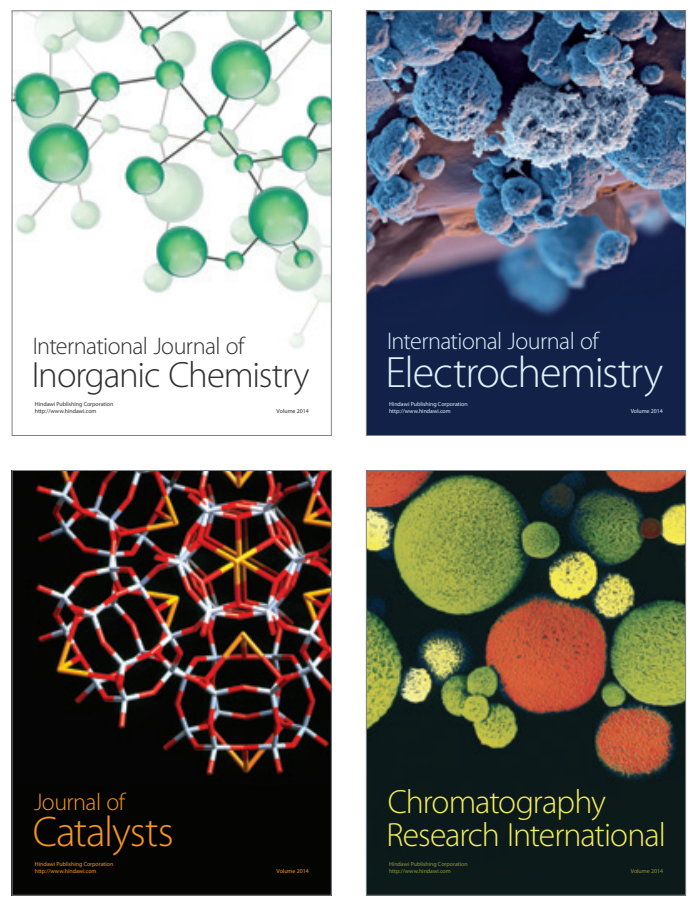


Journal of

Applied Chemistry
